УДК 543.054

\author{
A.E. Utesheva, M.M. Sergazina, M.B. Alimzhanova*, B.N. Kenesov \\ Center of Physical Chemical Methods of Research and Analysis, \\ al-Farabi Kazakh National University, Kazakhstan, Almaty \\ "E-mail: mereke.84@mail.ru
}

\title{
Determination of volatile organic compounds in Kazakhstan red wine by headspace solid-phase microextraction in combination with GC-MS
}

\begin{abstract}
An analytical method for determination of volatile organic compounds (VOCs) in Kazakhstan red wine was developed in this study. The volatile composition of red wine was determined by headspace SPME in combination with GC-MS. The DVB/CAR/PDMS fiber and the sample volume of $10 \mathrm{~mL}$ were chosen. The optimal conditions for HS-SPME were temperature of $30^{\circ} \mathrm{C}$ and extraction time of $60 \mathrm{~s}$. Addition of $3 \mathrm{~g} \mathrm{NaCl}$ and no $\mathrm{pH}$ adjusting were the most suitable parameters for extraction of VOCs from wine. The developed methodology enables to identify compounds referring to the following classes such as esters, alcohols, aldehydes, acids, ketones and naphthalenes and can be applied for forensic examination of Kazakhstan red wine.
\end{abstract}

Key words: Red Wine, HS-SPME, GC-MS, Volatile Organic Compounds.

\author{
А.Е. Утешева, М.М. Сергазина, М.Б. Алимжанова, Б.Н. Кенесов \\ Газ фазасынан қатты фазалы микроэкстракциямен бірлескен ГХ-МС әдісімен қазақстандық \\ қызыл шараптағы ұшқыш органикалық қосылыстарды анықтау
}

\begin{abstract}
Осы жұмыста қазақстандық қызыл шараптағы ұшқыш органикалық қосылыстарды анықтау әдісі шығарылған. Қызыл шараптың ұшқыш құрамы газ фазасынан қатты фазалы микроэкстракциямен бірлескен газ хроматографиясы - масс-спектрометрия әдісін қолдану арқылы анықталды. Сорбциялық жабынды ретінде ДВБ/ Кар/ПДМС талшығы ұсынылып, сынама көлемі 10 мл мөлшерінде алынды. ГФ-ҚФМЭ оңтайлы жағдайлары ретінде $30^{\circ} \mathrm{C}$ температура және 60 секунд уақыт алынды. $\mathrm{NaCl}$ тұзын 3 г мөлшерінде қосу экстракция тиімділігіне жағымды әсер етті. рН-ты реттеу қажеттілігі болған жоқ. Шығарылған әдістеме күрделі эфирлер, спирттер, альдегидтер, қышқылдар, кетондар және нафталиндер сияқты қосылыстар кластарын анықтауға мүмкіндік берді және жасалған тұжырымдар бойынша қазақстандық қызыл шарапты сараптауда қолданылуы мүмкін.
\end{abstract}

Түйін сөздер: қызыл шарап, ГФ-ҚФМЭ, ГХ-МС, ұшқыш органикалық қосылыстар.

А.Е. Утешева, М.М. Сергазина, М.Б. Алимжанова, Б.Н. Кенесов

Определение летучих органических соединений в составе красных Казахстанских вин методом парофазной твердофазной микроэкстракции в сочетании с ГХ-МС

Был разработан аналитический метод определения летучих органических соединений (ЛОС) в красном казахстанском вине. Компонентный состав вин определяли методом парофазной твердофазной микроэкстракции (ПФ-ТФМЭ) в сочетании с ГХ-МС. Было выбрано волокно DVB/CAR/PDMS, и объем пробы - 10 мл. Оптимальными условиями для ПФ-ТФМЭ были температура $30^{\circ} \mathrm{C}$ и время экстракции 60 секунд. Добавление трех грамм $\mathrm{NaCl}$ является наиболее подходящим параметром для экстракции летучих органических соединений из вин, а также не требует регулирования уровня рН. Разработанный метод позволяет определять соединения, относящиеся к таким классам, как сложные эфиры, спирты, альдегиды, кислоты, кетоны и нафталины, и может быть применен в криминалистической экспертизе красного казахстанского вина.

Ключевые слова: красное вино, ПФ-ТФМЭ, ГХ-МС, летучие органические соединения.

\section{Introduction}

The consumption of wine is rising in Asian region and becoming more popular in Kazakhstan and as a consequence the levels of its production are rising as well [1]. Marketing research shows that an overwhelming number of Kazakhstan wine consumers prefer domestic producer [2]. The increasing de- 
mand for this alcoholic product causes urgent need to develop methods of its quality control.

There are a large number of rapid and simple in performance methods for the analysis of the quality of wine abroad but in our Republic such methodology is not yet available.

Because of the various factors affecting the component composition of wine and the complexity of wine as a matrix for investigation, its analysis requires a special method of pre-concentration. Various methods of sample preparation were used for the analysis of wines at different time such as liquid-liquid extraction (LLE) with dichloromethane or its mixture with pentane, solid phase extraction (SPE) [3] and solid-phase microextraction (SPME) [4-6]. As there are a lot of purposes of wine analysis, a variety of techniques and methods have been developed for their investigation. Depending on the substances to be identified analysis of the wines is carried out by two analytical methods such as gas (GC) and liquid (HPLC) chromatography. Thus the determination of volatile and semi-volatile organic compounds is carried out by GC while phenolic compounds and PAHs are identified by HPLC $[7,8]$. Elemental analysis using mass spectrometry with inductively coupled plasma (ICP-MS) also takes place $[9,10]$.

$\mathrm{GC}$ is the most widespread method for wine analysis due to its high informativity. The following classes of compounds can be identified by means of GC such as esters, alcohols, aldehydes, ketones, acids, acetals, furans, lactones, terpenes, sulfur and nitrogen containing volatiles, all together these compounds are commonly called volatile aroma forming or just aromatic fraction (profile) of wines. SPME simplifies the process of sampling and sample preparation, reduces analysis time, completely eliminates the use of organic solvents and reduces financial costs. HS-SPME in combination with GC allows not only qualitatively but also quantitatively determining a wide range of substances in wines.

The goal of this study was to develop method based on HS-SPME for analysis of red wines of Kazakhstan origin.

\section{Experimental}

\subsection{Sample description}

Method optimization was carried out on a commercial table semi-sweet red wine "Bacchus"
(Kazakhstan, JSC «Bacchus», alcohol content of $10.0-12.0 \%$ ) which was collected directly from the brand store of manufacturer. Wine sample was in its original bottle and was refrigerated until the time of analysis. This wine was selected as the object of study due to its great demand comparing to other wines produced in Kazakhstan [2].

\subsection{Analytical reagents and supplies}

Sodium chloride, $\mathrm{NaCl}$ (reagent grade) was purchased from JSC "Reaktiv" (Novosibirsk, Russia), was baked out at $150^{\circ} \mathrm{C}$ for 2 hours prior to analysis to desorb VOCs; sodium hydroxide, $\mathrm{NaOH}$ (reagent grade) and hydrochloric acid, $\mathrm{HCl}$ (reagent grade) which were also purchased from JSC "Reaktiv" (Novosibirsk, Russia). Helium (99.995\% grade) (Orenburg, Russia) was used as the carrier gas in the GC system.

SPME fibers were obtained from Supelco (Bellefonte, PA, USA): divinylbenzene/Carboxenpolydimethylsiloxane (DVB/CAR/PDMS) and 100 $\mu \mathrm{m}$ PDMS. Prior to analyses, the fibers were conditioned at the manufacturer's recommended conditioning temperature. Clear screw cap vials for SPME $(20 \mathrm{~mL})$ with the polytetrafluoroethylene (PTFE)/silicone septa were purchased from Agilent (USA).

\subsection{Equipment}

GC-MS analysis were performed on 7890A/5973N system (Agilent Technologies, USA) equipped with Combi-PAL autosampler (CTC Analytics AG, Switzerland). Chromatographic separation was done using $30 \mathrm{~m}$ x $0.25 \mathrm{~mm}$ DB-35MS column having film thickness 0.25 micron and working at a constant flow rate of carrier gas (helium) of $1 \mathrm{~mL} / \mathrm{min}$. GC inlet worked in splitless mode at $240^{\circ} \mathrm{C}$, purge activation time was set to $5 \mathrm{~min}$. Oven temperature was programmed from $40^{\circ} \mathrm{C}$ (held for $2 \mathrm{~min}$ ) to $180^{\circ} \mathrm{C}$ at a heating rate of $2^{\circ} \mathrm{C} / \mathrm{min}$, followed by heating to $240^{\circ} \mathrm{C}$ at $10^{\circ} \mathrm{C} / \mathrm{min}$. GC run time was 78 minutes. Detection was performed in scan mode ( $\mathrm{m} / \mathrm{z}$ 34-300). Temperatures of MS interface, source and quadrupole were set to 240, 230 and $150^{\circ} \mathrm{C}$, respectively. All collected chromatograms were integrated, total peak area and areas of each peak were calculated, peaks were identified. Wine compounds were identified using collected mass spectra and Wiley $7^{\text {th }}$ edition and NIST'08 MS libraries. 
During the $\mathrm{pH}$ modification experiments, $\mathrm{pH}$ was controlled using I-160 MI pH-meter ("Izmeritelnaya Technika" LLC, Russia).

\subsection{Optimization of SPME conditions}

The initial experiments for method optimization were performed placing $8 \mathrm{~mL}$ of red wine into $20 \mathrm{~mL}$ vials keeping sample under continuous stirring at $500 \mathrm{rpm}$. Pre-incubation time was set to $5 \mathrm{~min}$ and thermal desorption into GC injector was carried out for $2 \mathrm{~min}$ at $240^{\circ} \mathrm{C}$ (except for experiments with optimization of ionic strength and $\mathrm{pH}$ ).

\subsubsection{Fiber selection}

Selection of the optimal fiber coating was carried out by analyzing 2 different wine samples (Table 1).

Table 1 - Wine samples

\begin{tabular}{|c|l|c|c|c|}
\hline \multicolumn{1}{|c|}{ The name and type of the wine } & \multicolumn{1}{|c|}{$\begin{array}{c}\text { Producer and country of manufacture; } \\
\text { [alcohol content, \%] }\end{array}$} & Sampling city & Volume, L & $\begin{array}{c}\text { Date of } \\
\text { sampling }\end{array}$ \\
\hline "Staryy Tbilisi", table semisweet red & $\begin{array}{l}\text { LLC “The Georgian Wines and Spirits } \\
\text { Company", Georgia, [11,5\%] }\end{array}$ & Almaty & 0.750 & 25.12 .2012 \\
\hline "Bacchus", table semisweet red* & JSC «Bacchus», Kazakhstan, [10-12\%] & Almaty & 0.750 & 07.03 .2013 \\
\hline
\end{tabular}

*Method optimization was carried out using this wine sample.

The performance of each fiber described in 2.2 was determined based on the number of identified compounds and their peak areas. Extraction was carried out at $40^{\circ} \mathrm{C}$ for $2 \mathrm{~min}$. The optimal fiber was chosen and was subsequently used in all further experiments.

\subsubsection{Sample volume experiments}

Experiments on determination of the optimal headspace to sample volume ratio were carried out by filling $20 \mathrm{~mL}$ vials with different wine sample volumes: 3, 5, 8, 10 and $13 \mathrm{~mL}$. Prepared samples were extracted at $40^{\circ} \mathrm{C}$ for $5 \mathrm{~min}$. Optimal ratio was determined and then was subsequently used in all further experiments.

\subsubsection{Optimization of extraction temperature} and time

To determine the optimal extraction time, wine samples $(10 \mathrm{~mL}$ in $20 \mathrm{~mL}$ vials) were extracted at $40^{\circ} \mathrm{C}$ using DVB/CAR/PDMS fiber for 10, 20, 30, 40, 60, 100, 120, 180, 240, 300 and $600 \mathrm{~s}$.

To determine the optimal extraction tempera- ture, wines samples $(10 \mathrm{~mL}$ in $20 \mathrm{~mL}$ vials $)$ were extracted by DVB/CAR/PDMS fiber for 5 minutes at $30,35,40$ and $45^{\circ} \mathrm{C}$. Higher temperatures were not studied to avoid changes in chemical composition of wine.

\subsubsection{Optimization of ionic strength and $\mathrm{pH}$}

Effect of strong electrolyte additive was studied by adding $0 ; 0.5 ; 0.7 ; 1.0 ; 3.0$ and $5.0 \mathrm{~g}$ of $\mathrm{NaCl}$ to $10 \mathrm{~mL}$ of red wine placed into $20 \mathrm{~mL}$ vials. The following SPME parameters were used: DVB/ $\mathrm{CAR} / \mathrm{PDMS}$ fiber; temperature $40^{\circ} \mathrm{C}$ and extraction time $5 \mathrm{~min}$; pre-incubation and desorption time $5 \mathrm{~min}$.

$\mathrm{pH}$ modification was conducted by adjusting wine's actual $\mathrm{pH}$ level to different $\mathrm{pH}$ values by adding $1 \mathrm{M} \mathrm{HCl}$ or $\mathrm{NaOH}$ solutions to $10 \mathrm{~mL}$ portion of table semisweet red wine placed into $20 \mathrm{~mL}$ glass vial. Extraction from the headspace above the samples was conducted using DVB/ CAR/PDMS fiber coating at $40{ }^{\circ} \mathrm{C}$ for $1 \mathrm{~min}$. Preincubation and desorption times were 5 and $2 \mathrm{~min}$, respectively. 


\section{Results and discussion}

\subsection{Fiber selection}

Table (2) below indicates the difference in extraction efficiency of two different fiber coatings on example of two table semisweet red wine of different origin country. In the wine samples were identified of different classes compounds: ethers (1-33), alcohols (34-38), aldehydes (39-40), acids (41-42), monoterpenes (43) styrenes (44), ketones (45-47), naphthalenes (49).

Table 2 - Compounds identified in Georgian and Kazakhstan wine using different fiber coatings

\begin{tabular}{|c|c|c|c|c|c|}
\hline \multirow{3}{*}{$\begin{array}{l}\text { Retention } \\
\text { time, min }\end{array}$} & \multirow{3}{*}{ Compound } & \multicolumn{4}{|c|}{ Peak area, $\mathrm{M}$ a.u. } \\
\hline & & \multicolumn{2}{|c|}{ Georgian wine } & \multicolumn{2}{|c|}{ Kazakhstan wine } \\
\hline & & $\begin{array}{c}\text { DVB/ } \\
\text { CAR/PDMS }\end{array}$ & $\begin{array}{l}\text { PDMS } \\
100 \mu\end{array}$ & $\begin{array}{c}\text { DVB/ } \\
\text { CAR/ PDMS }\end{array}$ & $\begin{array}{c}\text { PDMS } \\
100 \mu\end{array}$ \\
\hline 2.34 & Ethyl Acetate & 21.8 & 8.3 & 65.7 & 30.7 \\
\hline 3.52 & Propanoic acid, ethyl ester & - & - & 0.6 & 0.7 \\
\hline 4.31 & Propanoic acid, 2-methyl-, ethyl ester & 1.9 & 1.0 & 5.0 & 5.0 \\
\hline 4.80 & Acetic acid, 2-methylpropyl ester & - & - & 1.1 & 1.4 \\
\hline 5.72 & Butanoic acid, ethyl ester & 1.2 & 1.5 & 9.0 & 7.4 \\
\hline 6.24 & Acetic acid, butyl ester & - & - & - & 0.4 \\
\hline 6.73 & Propanoic acid, 2-hydroxy-, ethyl ester & 8.8 & 3.1 & 19.1 & 4.6 \\
\hline 7.17 & Butanoic acid, 2-methyl-, ethyl ester & 0.8 & 0.6 & 1.1 & 1.7 \\
\hline 7.43 & Butanoic acid, 3-methyl-, ethyl ester & 1.2 & 0.7 & 1.8 & 1.8 \\
\hline 8.67 & 1-Butanol, 3-methyl-, acetate & - & 6.9 & 114.9 & 42.3 \\
\hline 11.39 & Hexanoic acid, methyl ester & - & - & - & 0.2 \\
\hline 15.75 & Hexanoic acid, ethyl ester & 60.4 & 30.5 & 136.8 & 53.6 \\
\hline 16.76 & Acetic acid, hexyl ester & - & - & 17.8 & 4.4 \\
\hline 22.29 & Heptanoic acid, ethyl ester & - & - & 1.0 & 0.8 \\
\hline 23.39 & Acetic acid, heptyl ester & - & - & 0.2 & - \\
\hline 24.25 & Octanoic acid, methyl ester & 0.3 & - & 1.8 & 1,3 \\
\hline 25.02 & Ethyl sorbate & 22.7 & 3.8 & - & - \\
\hline 29.00 & Octanoic acid, ethyl ester & 150.6 & 26.5 & 692.5 & 382.1 \\
\hline 32.14 & Butanedioic acid, diethyl ester & 50.4 & 17.7 & 13.8 & 6.8 \\
\hline 32.75 & Methyl salicylate & 0.2 & 0.3 & - & - \\
\hline 35.23 & Propyl octanoate & - & - & 0.4 & - \\
\hline 35.54 & Nonanoic acid, ethyl ester & - & - & 1.4 & 0.6 \\
\hline 37.50 & Decanoic acid, methyl ester & - & - & 1.1 & 0.4 \\
\hline 37.73 & Acetic acid, 2-phenylethyl ester & 1.0 & - & 6.5 & 2.7 \\
\hline 38.28 & n-Caprylic acid isobutyl ester & - & - & 0.9 & 0.6 \\
\hline 41.76 & Decanoic acid, ethyl ester & 37.8 & 15.4 & 318.8 & 198.8 \\
\hline 42.20 & 4-Decenoic acid, ethyl ester & - & - & 19.3 & 16.5 \\
\hline
\end{tabular}




\begin{tabular}{|c|c|c|c|c|c|}
\hline 44.58 & $\begin{array}{l}\text { Isoamyl octanoate / Octanoic acid, } \\
\text { 3-methylbutyl ester }\end{array}$ & 0.3 & - & - & 3,4 \\
\hline 47.35 & $\begin{array}{l}\text { Butanedioic acid, diethyl ester / Diethyl } \\
\text { succinate }\end{array}$ & - & 0.6 & - & - \\
\hline 50.24 & n-Capric acid isobutyl ester & - & - & 0.5 & - \\
\hline 53.56 & Dodecanoic acid, ethyl ester & 0.4 & 0.6 & 7.2 & 2.5 \\
\hline 64.22 & Tetradecanoic acid, ethyl ester & - & 0.9 & - & - \\
\hline 73.59 & Hexadecanoic acid, ethyl ester & 2.4 & - & 1.4 & - \\
\hline 2.39 & Isobutyl alcohol / 1-Propanol, 2-methyl- & 10.6 & - & 26.8 & - \\
\hline 2.82 & 1-Butanol & - & - & - & 0,5 \\
\hline 3.97 & Isoamyl alcohol / 1-Butanol, 3-methyl- & 155.2 & 67.3 & 225.9 & 112.4 \\
\hline 8.58 & 1-Hexanol & 0.8 & - & 1.3 & - \\
\hline 31.87 & 3-Cyclohexene-1-methanol, $\alpha, \alpha, 4$-trimethyl- & - & - & 0.4 & - \\
\hline 6.26 & Hexanal & 0.3 & - & - & - \\
\hline 56.02 & Hexanal, 3-methyl- & 0.5 & - & - & - \\
\hline 2.70 & Acetic acid & 1.8 & 9.5 & 16.6 & - \\
\hline 24.19 & Hexanoic acid, 2-methyl- & - & 1.7 & - & - \\
\hline 34.41 & Vitispirane & - & 2.1 & - & - \\
\hline 39.22 & Benzene, 1-methoxy-4-(1-propenyl)- & - & 0.4 & - & - \\
\hline 22.81 & 2-Nonanone & 0.6 & 0.3 & - & - \\
\hline 25.36 & Acetophenone & 0.8 & - & - & - \\
\hline 34.50 & $\begin{array}{l}\text { 2(1H)-Naphthalenone, 3,4,4a,5,6,7- } \\
\text { hexahydro-1,1,4a-trimethyl- }\end{array}$ & 4.7 & - & - & - \\
\hline 41.48 & Naphthalene, 1,2-dihydro-1,1,6-trimethyl- & 2.2 & 1.6 & - & - \\
\hline
\end{tabular}

PDMS fiber identified only 30 volatile compounds in Kazakhstan wine comparing to DVB/ CAR/PDMS that extracted 35 components. DVB/ CAR/PDMS fiber had advantage at extracting greater number of polar compounds such as aldehydes, alcohols and ketones. Moreover, the peak areas of compounds extracted by PDMS fiber presented the low values, showing that PDMS fiber is not recommended for further quantitative analysis method development.

DVB/CAR/PDMS proved to be more suitable for analysis of wine of Kazakhstan origin.

\subsection{Sample volume}

Optimization of sample to headspace ratio can provide improved sensitivity. From practice, each analyte has its own optimal headspace to sample ratio. The goal of the experiment was to establish sample to headspace ratio that provides highest total peak area of wine VOCs using SPME-GCMS.

According to the obtained results, increase of sample volume from 3 to $10 \mathrm{~mL}$ leads to $20 \%$ increase of the total peak area followed by its slight $(5 \%)$ decrease.

Increase of sample volume from 3 to $10 \mathrm{~mL}$ leads to a linear increase of peak area of most analytes (Figure 1) followed by a slight decrease. Peak areas of the heaviest compounds, e.g., ethyl dodecanoate (Figure 1), increase linearly over the all studied range $(3-13 \mathrm{~mL})$. It can be due to the decreased distance between surfaces of sample and fiber coating leading to a faster extraction process, 
especially for compounds having lower volatility and diffusion coefficients.

Another advantage of higher sample volume is a decrease of air volume in contact with sample sur- face that allows minimizing sample oxidation during extraction.

Sample volume $10 \mathrm{~mL}$ was chosen as optimal and used in further experiments.
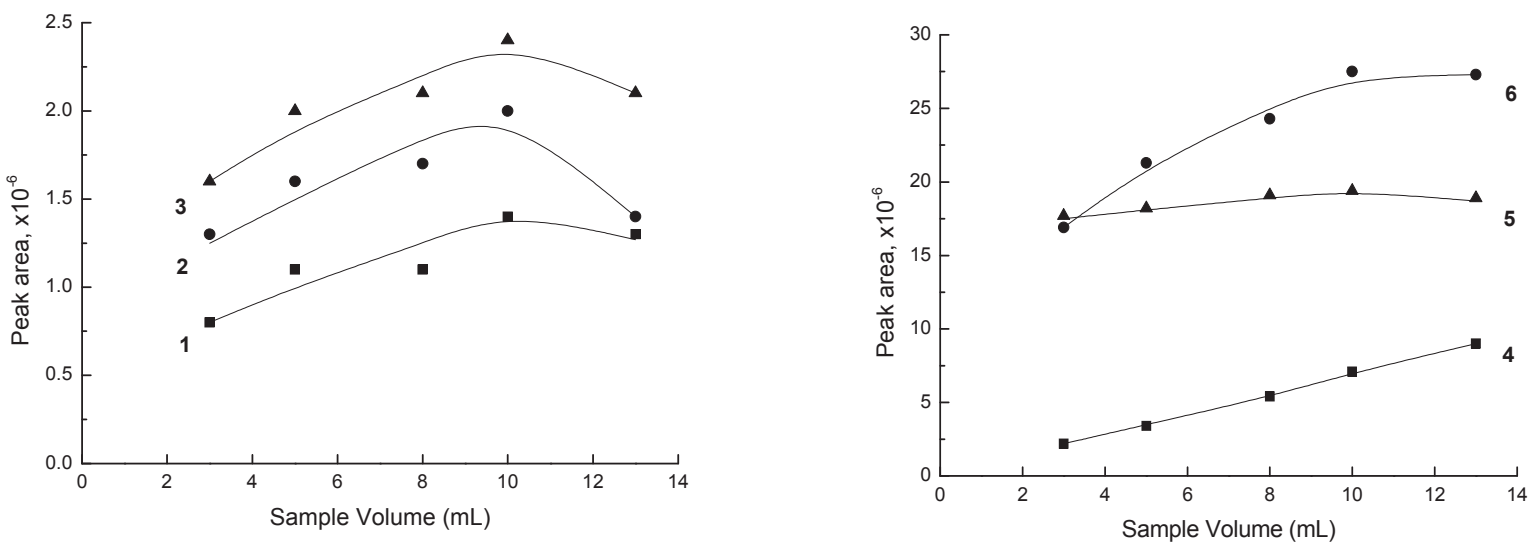

Figure 1 - Effect of ratio of the headspace to the sample volume on responses of individual compounds present in wine sample. Note: 1 - methyl decanoate, 2 - ethyl nonanoate, 3 - naphthalene, 1,2-dihydro-1,1,6-trimethyl-, 4 - ethyl dodecanoate, 5 - diethyl succinate, 6 - ethyl 9-decenoate

\subsection{Optimization of extraction conditions}

\subsubsection{Optimization of extraction time}

Increase of SPME time typically increases the response of analytes and hence decreases their detection limit. However, it is necessary to take into account the fact that the increase in the re- sponse of analytes can lead to an overload of the fiber coating and/or mass spectrometer.

According to the obtained results (Figures 2 ), increase of extraction time leads to the increase of total peak area of wine VOCs. The effect is more pronounced for the least volatile analytes, e.g. ethyl 9-decenoate and ethyl decanoate.

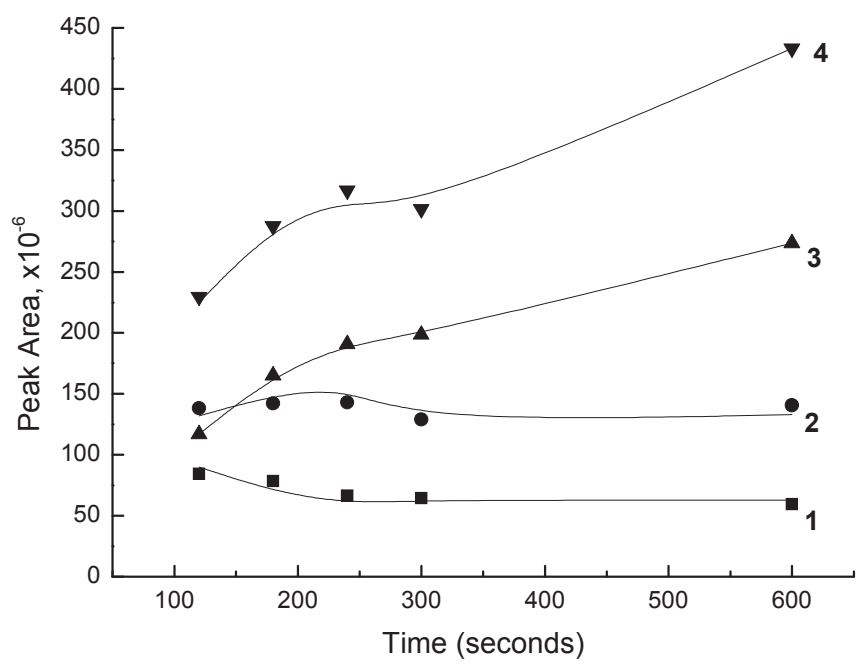

Figure 2 - Effect of extraction time on responses of individual wine VOCs. Note: 1 - ethyl butanoate $(\times 10), 2$ - ethyl hexanoate, 3 - ethyl 9-decenoate $(\times 10), 4$ - ethyl decanoate 
According to the literature data, when adsorptive fiber coatings are used, it is recommended to select extraction time lower than equilibrium is established. In this case analyte displacement due to competitive effect is avoided and the method reproducibility is increased.

The goal of another experiment was to study the effect of extraction time in the range between 10 and $180 \mathrm{sec}$. The following extraction times were tested: $10,20,30,40,60,100,120$ and $180 \mathrm{sec}$. According to the obtained data, total peak area increases in the whole range of extraction time. However, peak areas of individual compounds behave differently (Figure 3 ). Most volatile compounds are equilibrated after $60 \mathrm{sec}$ SPME while responses of the least volatile compounds almost linearly increase in the studied range.

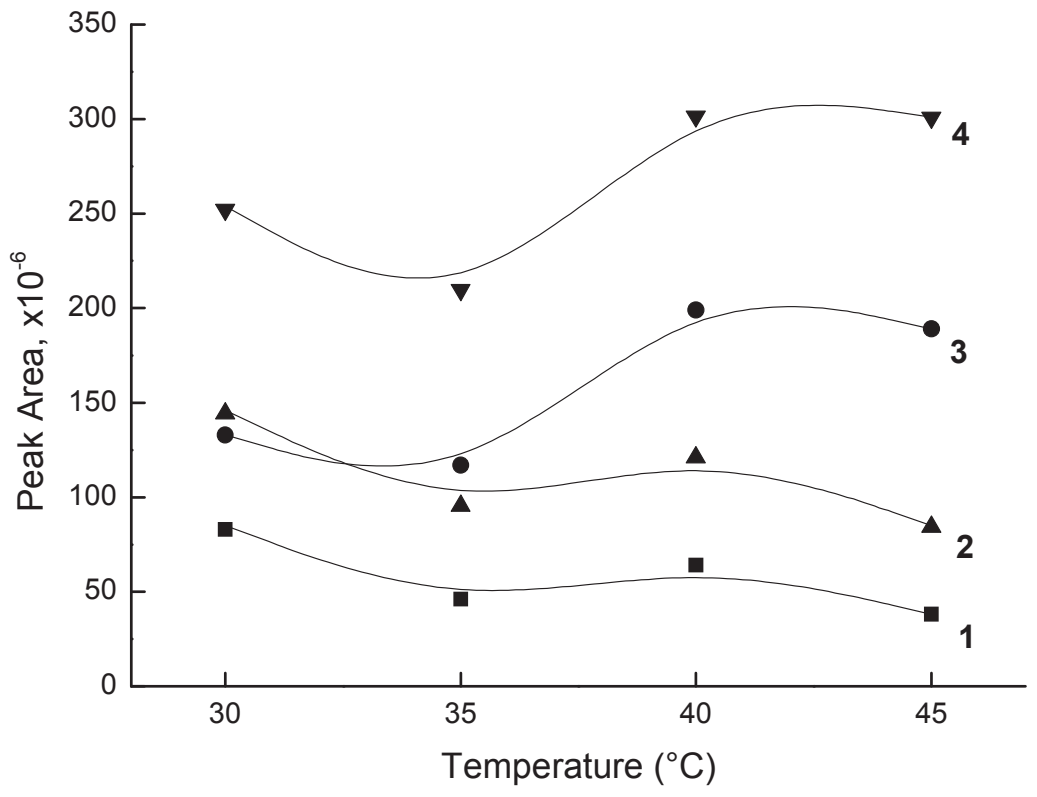

Figure 3 - Effect of extraction time on responses of individual wine VOCs. Note: 1 - ethyl hexanoate, 2 - isoamyl alcohol, 3 - ethyl decanoate, 4 - ethyl octanoate

Extraction time of 60 seconds was selected as optimal for SPME of VOCs from wine samples as it allows minimizing fiber overload along with maximum response of analytes.

\subsubsection{Optimization of extraction temperature}

During extraction of VOCs from headspace above sample, increase of the temperature can lead to substantial increase of SPME efficiency due to increase in vapor pressures of analytes. The goal of this experiment was to study the effect of temperature on the extraction efficiency of wine VOCs from headspace above samples. Temperatures higher than $45^{\circ} \mathrm{C}$ were not tested to avoid thermal decomposition of analytes.

According to the obtained data, increase of extraction temperature from 30 to $35^{\circ} \mathrm{C}$ leads to $30 \%$ increase in total peak area followed by its further gradual decrease. Maximum total peak area was observed at $35^{\circ} \mathrm{C}$. Considering the effect of extraction temperature on responses of individual compounds (Figure 4) present in wine sample it is seen that extraction efficiency of highly volatile compounds decreases due to reducing of distribution coefficient between the gas phase and the fiber coating but for the least volatile compounds such as ethyl 9-decenoate and ethyl decanoate it increases. 


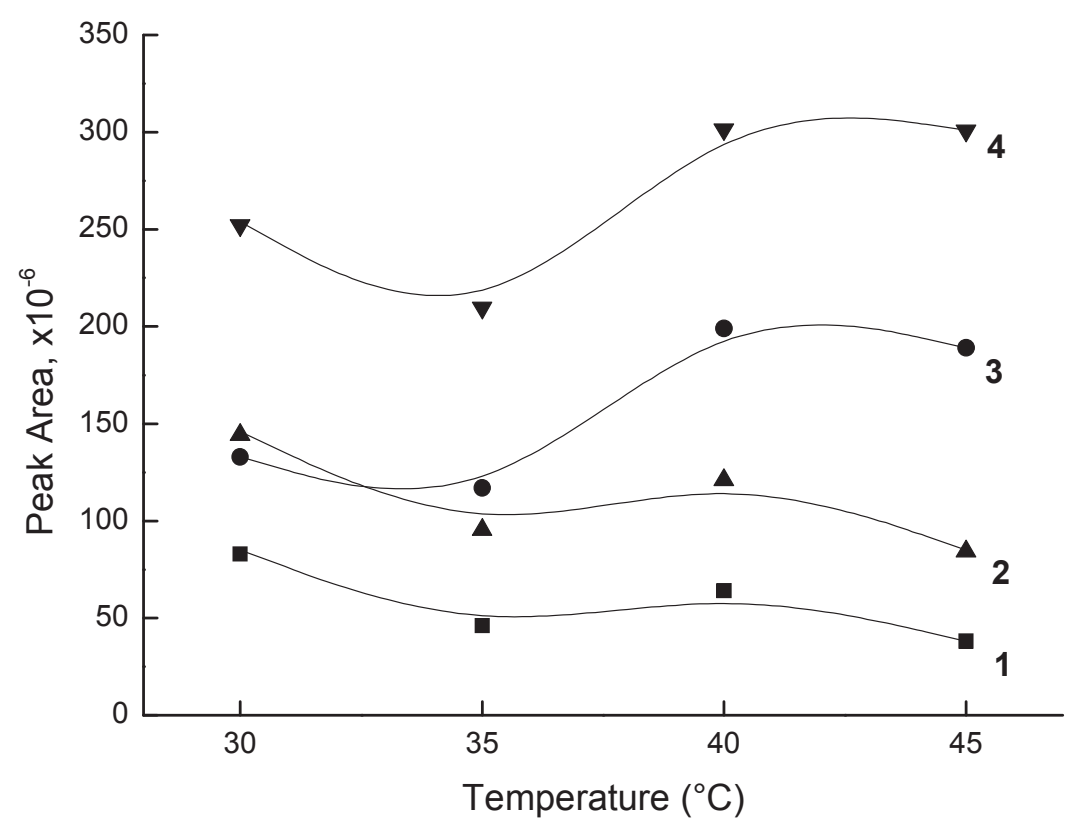

Figure 4 - Effect of extraction temperature on responses of individual wine VOCs. Note: 1 - ethyl butanoate $(\times 10), 2-$ ethyl hexanoate, 3 - ethyl 9-decenoate $(\times 10), 4$ - ethyl decanoate

When choosing the optimal temperature for HSSPME preference is given to a temperature of $30^{\circ} \mathrm{C}$ as it allows observing the same amount of compounds as the other tested temperatures. There might be side reactions in the liquid phase and on the fiber conditioned by further temperature increase. The other advantage of the selected temperature is proximity to room temperature which simplifies the extraction process allowing to work without the autosampler and significantly expands the applicability of techniques in the practice of forensic examination. Therefore the temperature of $30^{\circ} \mathrm{C}$ was chosen as an optimum.

\subsection{Optimization of the matrix conditions}

\subsubsection{Strong electrolyte additive}

According to the results (Figure 5), addition of $3 \mathrm{~g} \mathrm{NaCl}$ to wine sample leads to $65 \%$ increase in total peak area as well as in value of peak area of individual compounds. Further increase of $\mathrm{NaCl}$ mass added to the sample leads to a decrease of total peak area and peak areas of most peaks due to saturation of sample with salt.
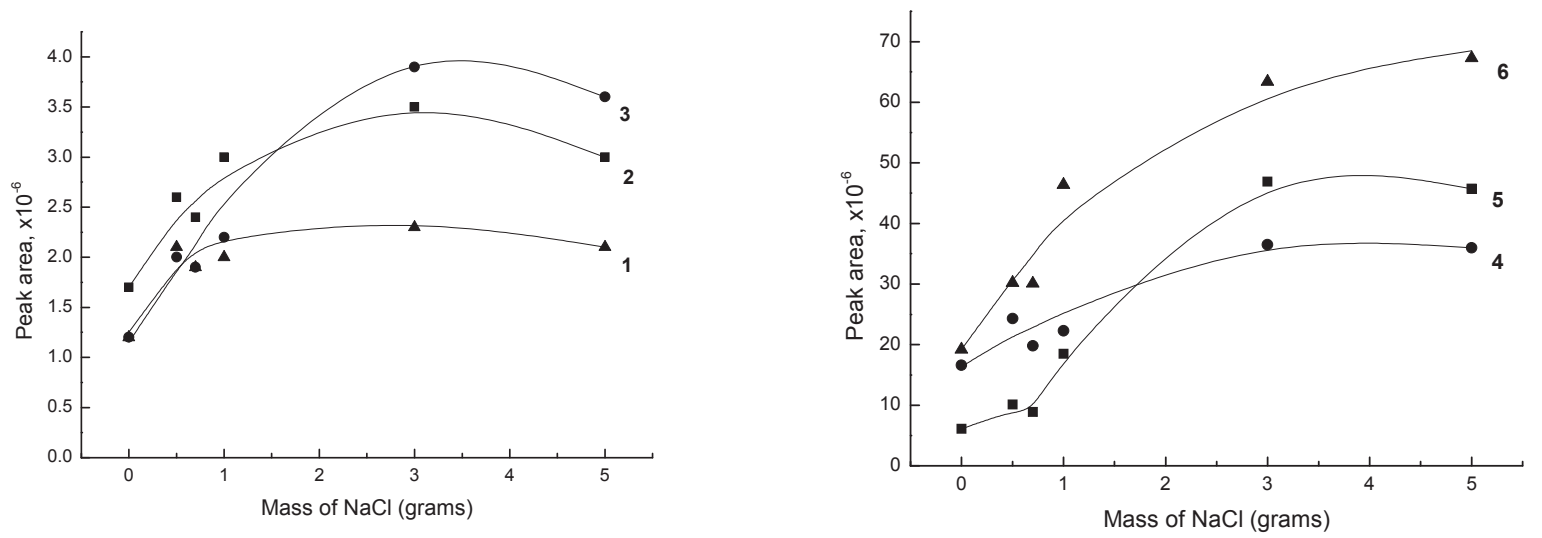

Figure 5 - Effect of the amount of strong electrolyte added onto peak areas of individual wine VOCs. Note: 1 - methyl decanoate, 2 - ethyl nonanoate, 3 - ethyl heptanoate, 4 - ethyl lactate, 5 - vitispirane, 6 - diethyl succinate 
Thus, addition of $3 \mathrm{~g}$ of sodium chloride to red wine samples was selected as optimum.

\subsubsection{Effect of $p H$}

Extraction efficiency of ionic species may be increased by $\mathrm{pH}$ modification. Wine samples are slightly acidic. For the selected wine sample $\mathrm{pH}$ was measured to be 3.05. By theory, most efficient extraction of acidic compounds is achieved at low $\mathrm{pH}$. The goal of the experiment was to establish the optimal $\mathrm{pH}$ for most efficient SPME of VOCs from wine samples.

According to the obtained results, total peak

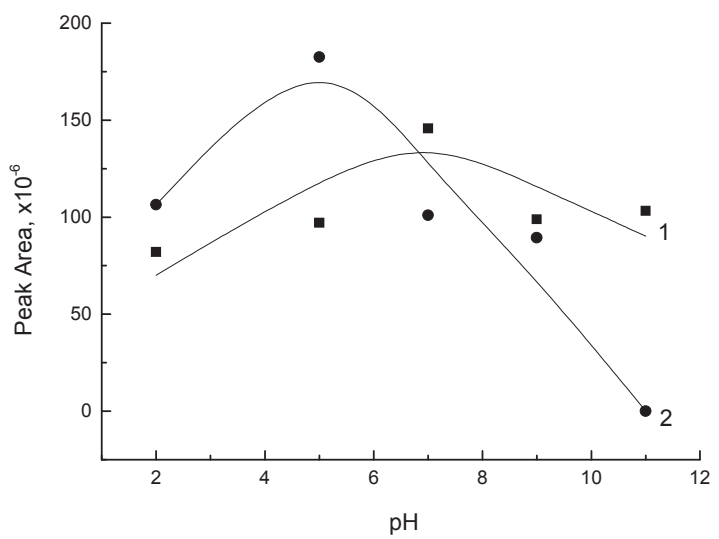

area in $\mathrm{pH}$ range between 2 and 9 remains virtually constant followed by a rapid decrease when $\mathrm{pH}$ becomes 11 .

However, response of ethyl decanoate rapidly decreases when $\mathrm{pH}$ becomes less than 6 (Figure 6 ). For most analytes the highest response was observed at $\mathrm{pH} 7$ (Figure 12). Slight changes in chemical composition of $\mathrm{pH}$-modified wine samples were observed. That can be caused by chemical equilibrium shift in samples leading to undesirable processes.

Taking into account this fact, it was decided to analyze samples of red wine at their original $\mathrm{pH}$ levels.

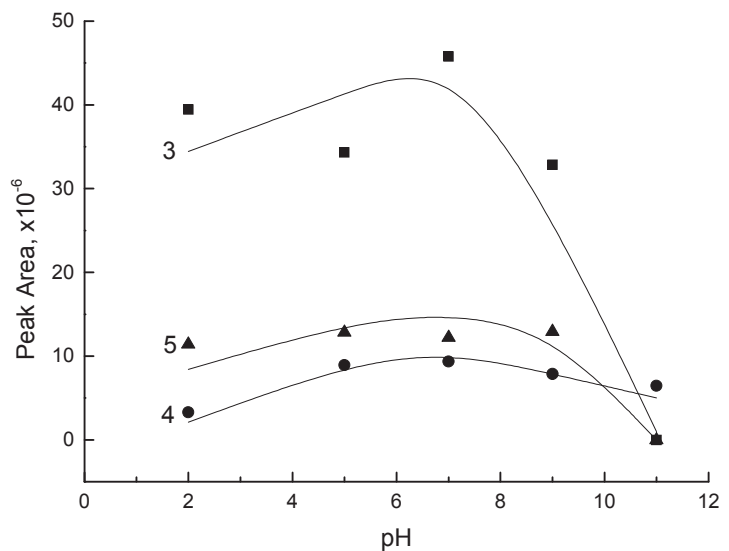

Figure 6 - SPME-GC-MS peak area of individual compounds depending on wine sample pH: 1 - isoamyl alcohol; 2 - ethyl decanoate; 3 - ethyl acetate; 4 - 2-methyl-1-propanol; 5 - hexyl acetate

\section{Conclusions}

Thus, the following results were obtained for Kazakhstan red wine analysis. Experiment with samples of wine of different origin country showed that for analysis of Kazakhstan red wine DVB/CAR/ PDMS $50 / 30 \mu \mathrm{m}$ is more sensitive than PDMS100. Due to maximum response of analytes at 10 $\mathrm{mL}$ that volume was chosen as optimum ratio of the headspace to the sample volume. A temperature of $30^{\circ} \mathrm{C}$ was selected as an optimum. Since we used DVB/CAR/PDMS coating and its effective operating range is interval before reaching equilibrium it was decided to analyze red wine samples at extraction time of $60 \mathrm{~s}$. Several matrix modification experiments were carried out. Three grams of sodium chloride were chosen as an optimum as their addition positively affects extraction efficiency. It was decided to analyze samples of red wine at their original $\mathrm{pH}$ level since $\mathrm{pH}$ modification slightly increases extraction efficiency. The developed methodology can be applied for forensic examination of Kazakhstan red wine samples as it gives the great amount of information collected about the sample composition.

\section{Acknowledgements}

The authors gratefully acknowledge International Science and Technology Center (ISTC) and World Federation of Scientists. This work was supported by ISTC through project K-1983 and by World Federation of Scientists through Scholarship for Young Scientists. 


\section{References}

1 Wine consumption in the world will grow at the expense of Asia. http://www.meta.kz/351588-potreblenie-vina-v-mire-budetrasti-za-schet-azii.html 15 декабря $2009 \underline{\text { Interfax.kz }}$

2 Wine consumption in Kazakhstan, 2002. http://www.tns-global.kz/ru/publication/publ74.php

3 I. Andujar-Ortiz, M.V. Moreno-Arribas, P.J. Martín-Álvarez, M.A. Pozo-Bayón. Analytical performance of three commonly used extraction methods for the gas chromatography-mass spectrometry analysis of wine volatile compounds // J. Chromatogr. A 2009. - № 1216. - P. 7351-7357

4 Guillaume Antalick, Marie-Claire Perello, Gilles de Revel. Development, validation and application of a specific method for the quantitative determination of wine esters by headspace-solid-phase microextraction-gas chromatography-mass spectrometry // Food Chemistry. - 2010. - № 121. - P. 1236-1245

5 Elisabete Paula Barros, Nathalie Moreira, GiulianoElias Pereira, Selma Gomes Ferreira Leite, Claudia Moraes Rezende, Paula Guedes de Pinho. Development and validation of automatic HS-SPME with a gas chromatography-ion trap/mass spectrometry method for analysis of volatiles in wines // Talanta. - 2012. - № 101. - P. 177-186

6 Lucie Setkova, Sanja Risticevic, Janusz Pawliszyn. Rapid headspace solid-phase microextraction-gas chromatographic-timeof-flight mass spectrometric method for qualitative profiling of ice wine volatile fraction I. Method development and optimization // Journal of Chromatography A. - 2007. - № 1147. - P. 213-223

7 M.A. Gómez Gallego, E. G. García-Carpintero, E. Sánchez-Palomo, M.A. G. Viñas, I. Hermosín-Gutiérrez. Impact of alternative technique to ageing using oak chips in alcoholic or in malolactic fermentation on volatile and sensory composition of red wines // Food Research International. - 2012. - № 48. - P. 7-15

8 L. R. Silva, P. B. Andrade, P. Valentao, R. M. Seabra, M. E. Trujillo, Encarna Velazquez. Analysis of non-coloured phenolics in red wine: Effect of Dekkera bruxellensis yeast // Food Chem. - 2005. - № 89. - P. 185-189

9 S. M. Rodrigues, M. Otero, A. A. Alves, J. Coimbra, M. A. Coimbra, E. Pereira, A. C. Duarte. Elemental analysis for categorization of wines and authentication of their certified brand of origin // Journal of Food Composition and Analysis - 2011. - № 24. P. $548-562$

10 A. E. Martin, R. J. Watling, G. S. Lee. The multi-element determination and regional discrimination of Australian wines // Food Chemistry - 2012. - № 133. - P. 1081-1089 